\title{
デュプイトレン拘縮における手掌腱膜の化学的分析
}

\author{
大分医科大学整形外科 \\ 高 見 博 昭・麻 生 邦一 \\ 友 成一徳・真 角 昭 吾
}

\section{Chemical Analysis of Palmar Aponeurosis in Dupuytren's Disease}

by

\author{
Hiroaki Takami, Kuniichi Aso, Kazunori Tomonari \\ and Shogo Masumi
}

Department of Orthopedic Surgery, Medical College of Oita

\begin{abstract}
Collagen and mucopolysaccharides of the palmar aponeurosis in Dupuytre's contracture were compared with those of the normal palmar aponeurosis and palmaris longus tendon. The collagen was extracted by salt differential method and analysed by SDS-polyacrylamide gel electrophoresis. The results showed that collagen was mainly composed of type I, and slightly of type V, but type III collagen was not found. No difference was seen between Dupuytren's aponeurosis and normal aponeurosis. In the amino acid composition of $1.5 \mathrm{M}$ fraction collagen in Dupuytren's aponeurosis, hydroxyproline decreased in $\alpha_{1}$ (I) chain, whereas serine increased and Hydroxyproline decreased in $\alpha_{2}$ (I) chain. Analysis of the glycosaminoglycan of Dupuytren's aponeurosis revealed the extremely increased dermatan sulfate, in addition to the appearance of chondroitin sulfate, hyaluronic acid and heparan sulfate, which resembled the skin pattern.
\end{abstract}

デュプイトレン拘縮における手掌腱膜は, 正常手掌 腱膜と較べ，コラーゲン・タイプIIIが多いと言われて いるが, glycosaminoglycans（以下 GAG と略す）に ついての報告はみられない.今回我々は本疾患につい て,コラーゲンの他 $\mathrm{GAG}$ の変化について正常腱膜を対 照として検討した。

\section{材料および方法}

73 才男子および 54 才男子のデュプイトレン拘縮の手 掌腱膜 (湿性重量 $861 \mathrm{mg}$ および $1,234 \mathrm{mg}$ )を用いた。 液体窒素にて凍結粉砕後, homogenize し, $0.5 \mathrm{M}$ 一酢 酸中にてペプシン消化を行い, 上清を $1 \mathrm{M}$-Trisにて

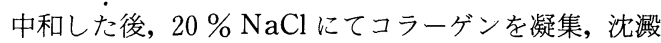
させた.これを $1 \mathrm{M}-\mathrm{NaCl} 0.05 \mathrm{M}$-Tris ・ $\mathrm{HCl}$ buffer (pH 7.5)にて溶解し, $1.5 \mathrm{M}, 1.9 \mathrm{M}, 2.4 \mathrm{M}$ の各塩 濃度にて順次透析を行いコラーゲンを分別沈澱・回収 した(表 1 ).抽出したコラーゲンを用い,(1) 3.6 M Urea
を含んだ $5 \%$ 濃度の SDS-polyacrylamide gel 電気泳 動を行った.（2）1.5 Mで塩析されたコラーゲンについ て, WHATMANN の CM-32 を用い CM セルロース・ クロマトグラフィーを行った. (3) 1.5 M画分のコラー ゲンについて HITACHI：835-30 自動アミノ酸分析器 を用いて，アミノ酸組成を調べた。また採取したデュ プイトレン腱膜の一部（乾燥重量 $51.1 \mathrm{mg}$ および 315 $\mathrm{mg}$ )を $\mathrm{NaOH}$, プロナーゼ処理後, 粗 $\mathrm{GAG}$ を得た(表 2 ).これを用い, (1)ウロン酸測定を行った. (2)アセテ ート膜電気泳動 ( 1 次元泳動液に 0.1 Mピリジンー 0.47 $\mathrm{M}$ ギ酸液を, 2 次元に $0.1 \mathrm{M}$ 酢酸バリウム液を用いた） を行った。これによって, GAG 成分を分離し, 定性を 行った. (3) dimethylsulphoxide (以下 DMSO と略す.) を用いて定量される GAG 各成分について調べた ${ }^{3) 5)}$.

結果

酸可溶性コラーゲンの全回収量はそれぞれ $65.4 \mathrm{mg}$ ， 


\section{表1 METHODS}

$\downarrow$ homoginize

$\downarrow$ Pepsin digestion in $0.5 \mathrm{M} \mathrm{AcOH}$

$\downarrow \quad$ centrifugation

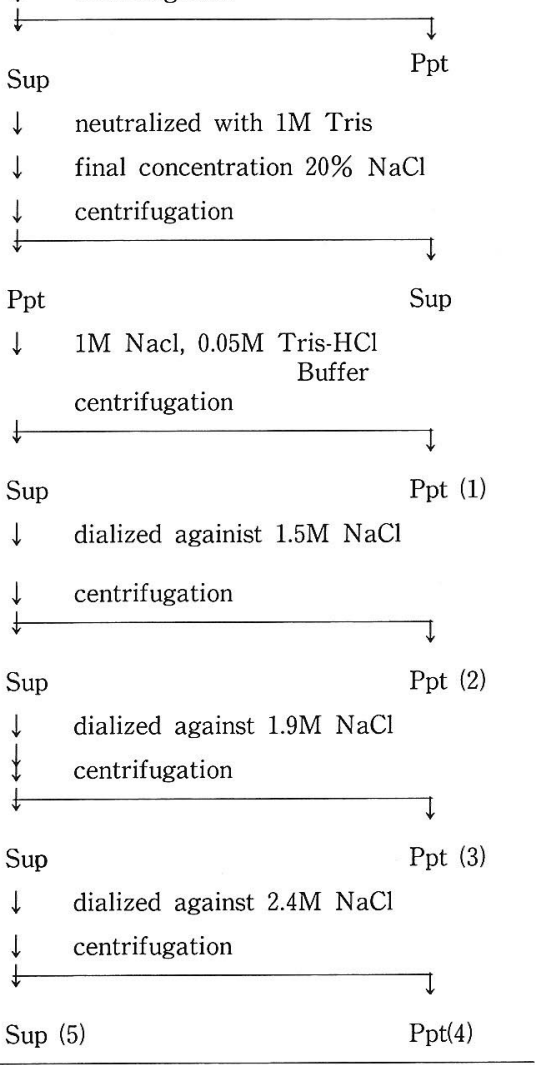

表2 酸性ムコ多糖の分離方法

試料（細片）

脱脂, 脱水 メタノール十タロロホルム $(2: 1)$ 液 乾燥智トン (99\%以上) 乾燥

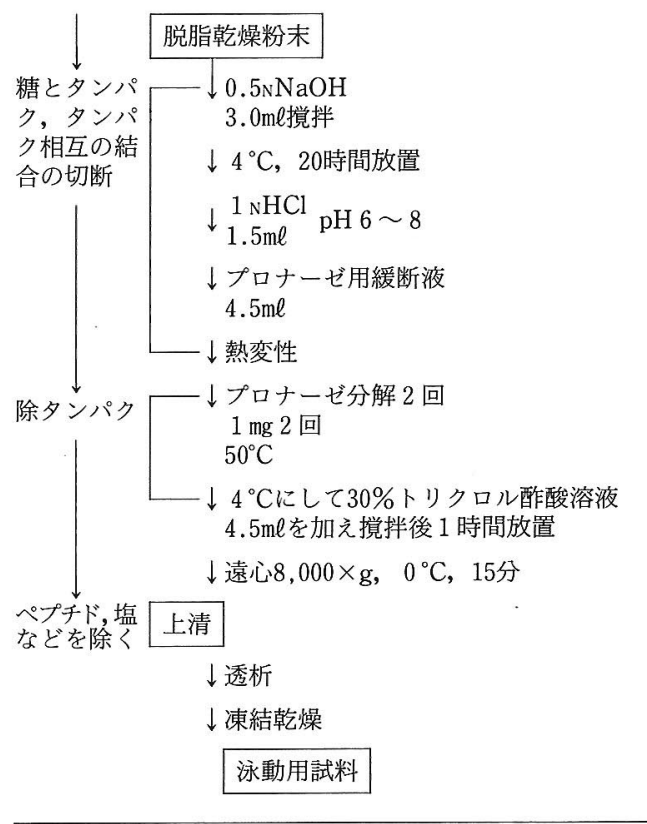

$65.8 \mathrm{mg}$ であった.デュプイトレン腱膜コラーゲンの 1.5 $\mathrm{M}, 1.9 \mathrm{M}, 2.4 \mathrm{M}$ 各分画の電気泳動パターンをみると, 各分画ともに I 型コラーゲンが, 主要構成成分であり, III型コラーゲンは検出されなかった。

しかし 2.4 M上清画分にて, Minor Component とし

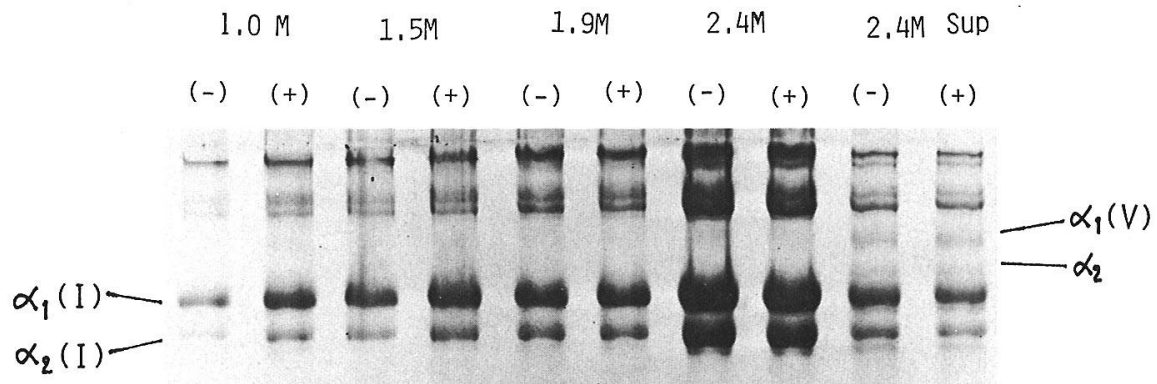

SDS-PAGE

図 1 Dupuytren's Aponeurosis 


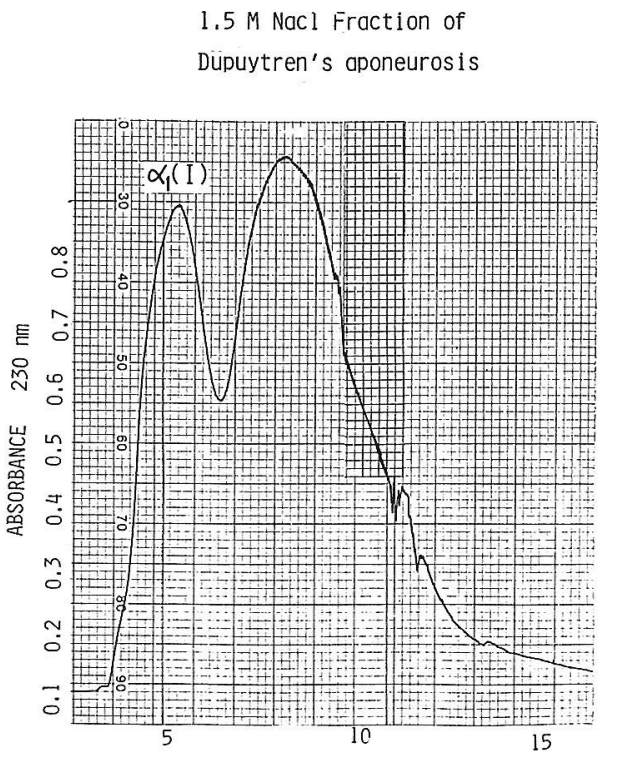

図 2 Chromatography

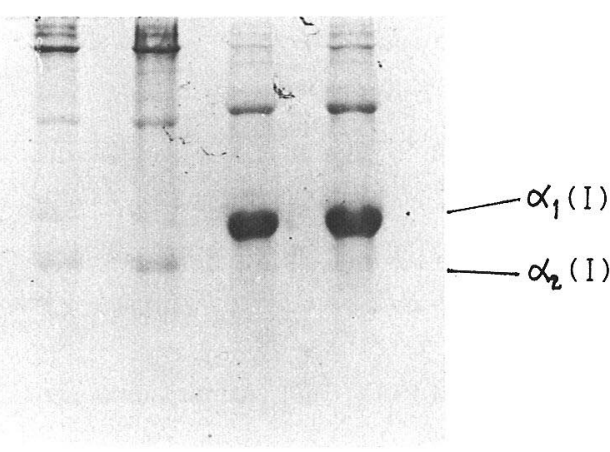

SDS.PAGE

图 $31.5 \mathrm{M}$ Naxl Fraction of Dupuytren'S aponeurosis

てV型コラーゲンが見出された（図 1 ).

$1.5 \mathrm{M}$ 画分を $\mathrm{CM}$ セルロース・イオン交換クロマトグ ラフィーにて分離すると, 2 つのピークが得られた(図 2 ). 各ピークを再びSDS-PAGEにて検討した処，低 イオン強度で溶出される最初のピークの成分は $\alpha_{1}$ (I) であり，次のピークは $\alpha_{2}$ (I) であった（図 3 ）。一方 III型成分はこの CM セルロースによる分画でも見出さ れなかった。また各成分のアミノ酸分析を見ると，表 3 の如く $\alpha_{1}$ (I) 鎖ではヒドロキシプロリン (Hypro) の減少， $\alpha_{2}$ (I ) 鎖ではセリン (Ser) の増加と Hypro

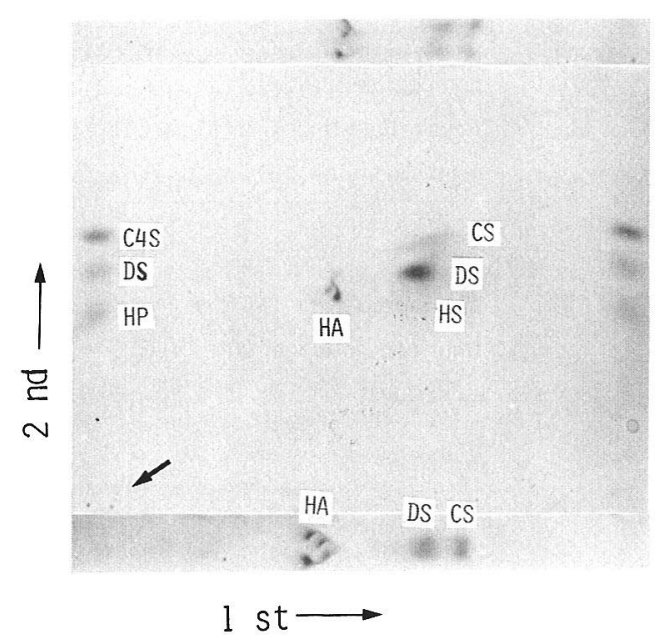

図4 Dupuytren's Aponeurosis

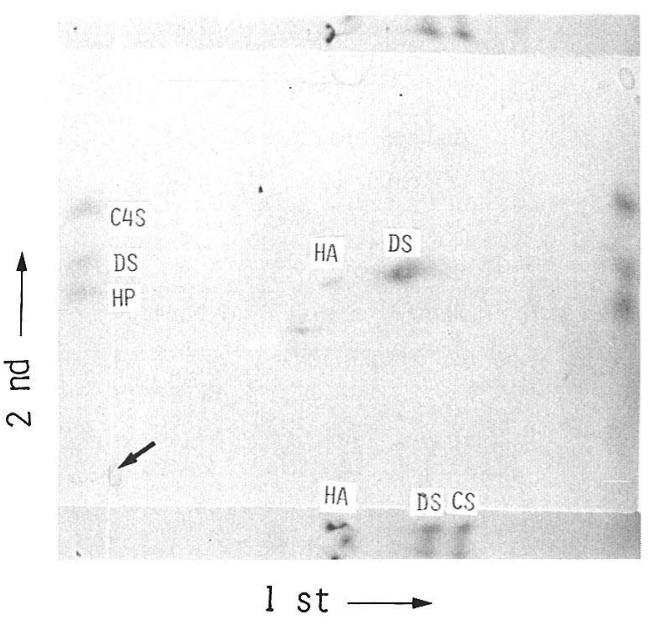

図 5 Normal Aponeurosis

の減少をみとめた。またここでもシスティン (Cys) の 存在がみとめられないことからも，III型コラーゲンが $1.5 \mathrm{M}-\mathrm{NaCl}$ 画分にも存在しないことがわかる到.

結合組織の多糖成分である GAG をアセテート膜電気 泳動によって検討したところ，デュプイトレン腱膜で は，ヒアルロン酸 (HA)，デルマタン硫酸 (DS)，コ ンドロイチン硫酸 (CS), ヘパラン硫酸 (HS) が検出 された (図 4 ). 正常手掌腱膜の GAG, 手掌腱膜より 移行する正常長掌筋腱の GAG の電気泳動㥗 5 , 図 6 にそれぞれ示す.デュプイトレン腱膜の GAGの泳動パ 
表3 デュプイトレン拘縮腱膜のアミノ酸組成

\begin{tabular}{|c|c|c|c|c|}
\hline \multirow[b]{2}{*}{ Sample } & \multicolumn{2}{|c|}{ Dupuytren (1.5M Franction) } & \multicolumn{2}{|c|}{ ヒトコラーゲン $\alpha$ 鎖のアミノ酸組織成 } \\
\hline & $\alpha_{1}(\mathrm{I})$ & $\alpha_{2}(\mathrm{I})$ & $\alpha_{1}(\mathrm{I})$ & $\alpha_{2}(\mathrm{I})$ \\
\hline \multicolumn{5}{|l|}{ DATE } \\
\hline \multicolumn{5}{|l|}{$\mathrm{CySO}_{3} \mathrm{H}$} \\
\hline ASP & 44 & 48 & 46 & 45 \\
\hline Thr & 17 & 20 & 18 & 18 \\
\hline Ser & 39 & 64 & 35 & 30 \\
\hline GLU & 76 & 84 & 77 & 70 \\
\hline GLy & 327 & 323 & 330 & 331 \\
\hline ALa & 115 & 101 & 119 & 105 \\
\hline Cys & 2 & 0 & N.D & N.D \\
\hline $\mathrm{VaL}$ & 17 & 21 & 19 & 35 \\
\hline Met & 4 & 6 & 5.3 & 4.7 \\
\hline ILe & 8 & 14 & 8.2 & 16 \\
\hline Leu & 19 & 24 & 20 & 33 \\
\hline Tyr & 2 & 5 & 2.1 & 3.2 \\
\hline Phe & 12 & 10 & 13 & 11 \\
\hline Lys & 27 & 22 & 27 & 20 \\
\hline \multicolumn{5}{|l|}{$\mathrm{NH}_{3}$} \\
\hline HIS & 3 & 8 & 4 & 10 \\
\hline \multicolumn{5}{|l|}{ Trp } \\
\hline Arg & 48 & 43 & 49 & 51 \\
\hline Pro & 135 & 109 & 118 & 114 \\
\hline Hypr & 93 & 80 & 115.1 & 106.2 \\
\hline HyLy & 7 & 7 & 10 & 12 \\
\hline 計 & 1006 & 992 & 1015.7 & 1015.1 \\
\hline
\end{tabular}

(アミノ酸1000個当り)

ターンは正常手掌腱膜や長掌筋腱の泳動パターンより も，皮膚 GAGの泳動パターンに近いことを示している. GAGの各成分について DMSO 抽出法により HA と DS との比をみるとデュプイトレン腱膜が各サンプルに おいて 1 対 5 とよび 1 対 11 であり, 正常腱膜が 1 対 2 および 1 対 5 ，長掌筋腱が 1 対 2 であった。いずれも
デュプイトレン腱膜においては DS が著明に増えている ことがわかった。

考

1983 年 Gelberman らはデュプイトレン拘縮の腱膜に おいて Myofibroblast が重要な働きをしていることを 


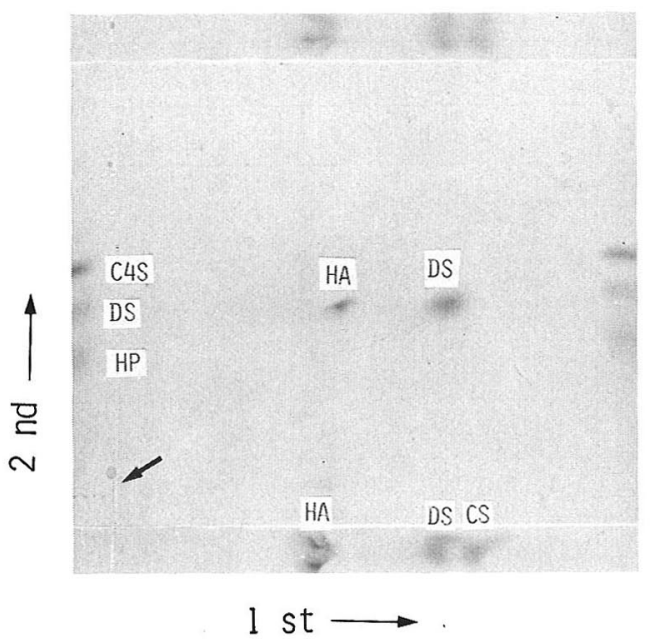

目6 Palmaris Longus tendon

指摘し,コラーゲン合成の促進, Turnover の元進とと もにIII型コラーゲンの有意の増加を認めたと報告して いる4). 1901 年 Blickley-Parsons らも GAG の増量と ともにIII型コラーゲンが増えていることを報告してい る1). 今回我々のコラーゲン分析では，I 型コラーゲン が主で, III型コラーゲンは析出されず, $2.4 \mathrm{M}$ 上清画分 においてV型コラーゲンが析出された。V型コラーゲ ンは膜に存在し，未熟な結合組織や，肥大性疫痕組織 にも豊富に存在していると言われているが，その存在 意義については今後の検索が待たれるところである ${ }^{2(6) 7)}$. またムコ多糖分析の結果は，デュプイトレン腱膜の電 気泳動パターンは正常腱膜や長掌筋腱のそれと異なり, ヒアルロン酸，コンドロイケン硫酸，へパラン硫酸の 出現とともに, デルマタン硫酸の有意の増加をみた ${ }^{8) 99}$. これは皮膚型パターンであり，デュプイトレン腱膜の GAG からは腱ではなく皮膚に近くなるという興味ある 知見を得た。

$$
\text { ま と め }
$$

1. デュプイトレン拘縮の腱膜および正常の手掌腱 膜についてコラーゲンとムコ多糖の化学的分析を行っ た.

2.デュプイトレン腱膜に正常腱膜ともに，I 型コ
ラーゲンが主要構成成分であり，III型はみられなかっ た。

3. 一方両者ともにV 型コラーゲンがみとめられた。

4.アミノ酸組成をみると，デュプイトレン腱膜の $\alpha_{1}$ （I）鎖ではヒドロキシプリンの減少， $\alpha_{2}$ （I）鎖 ではセリンの増加及びヒドロキシプロリンの減少をみ た.

5. 酸性ムコ多糖分析ではデュプイトレン腱膜は皮 膚型に近いことがわかった。

\section{参 考 文 献}

1) Brickley-Parsons, D. et al.: Biochemical changes in the Collagen of the Palmar Fascia in Patients with Dupuytren's Disease. J. Bone and Joint Surg., 63-A : 787-797, 1981

2）岩田 久：整形外科領域におけるムコ多梼分析．整 形災害外科, $24: 1399-1408,1983$.

3）藤本大三郎・他：コラーゲンの調整・コラーゲンの 分析. 31-77, 講談社, 東京, 1985 .

4) Gelberman, R. H.: Dupuytren's Contracture. J. Bone and Joint Surg., 62-A : 425-432, 1980.

5）畑隆一郎：蛋白質・核酸・酸素。18：848-857， 1973.

6）梶川欽一郎：コラーゲン分子の生化学. 結合組織, 150-158, 金原出版株式会社, 東京, 1984 .

7）新名正由：整形外科領域におけるムコ多糖分析．整 形災害外科，26：1409-1425，1983.

8）大平敦彦：細胞表面に存在するへパラン硫酸。プロ テオグリカンの構造と機能. 代謝, $21: 305-313,1984$.

9）瀬野信子：プロテオグリカンの構造と機能. 代謝, $18: 603-612,1981$.

10）高橋礼子：アミノ酸組成の決定法。タンパク質の化 学II, 41-72, 東京化学同人, 1984.

質 問産業医科大学 鈴木 勝己 再発をくり返すものも同じ結果でしょうか.

解 答 大分医科大学 高見 博昭

再発例についての分析はまだ行っていません。

Gelberman らは, 電顕的には初発例に見られる特徴 的な Myofibroblast の存在に対して，再発例に扔いて は, 大きな Microtubule の存在を指摘していますので, 生化学的にもやはり違いがあることも考えられます。 今後，機会があれば調べてみようと思っています。 